\title{
POWSZECHNIE OBOWIĄZUJĄCE AKTY LEGISLACJI ADMINISTRACYJNEJ JAKO PRZEDMIOT KONTROLI TRYBUNAŁU KONSTYTUCYJNEGO
}

\begin{abstract}
Przedmiotem rozważań $\mathrm{w}$ niniejszym artykule są problemy związane $\mathrm{z}$ możliwością weryfikacji konstytucyjności aktów powszechnie obowiązującego prawa, stanowionego przez terenowe organy administracji publicznej. W opracowaniu omówiono konstytucyjnie określony zakres działania Trybunału Konstytucyjnego jako organu sprawującego w Polsce władzę sądowniczą, stojącego na straży konstytucyjności obowiązującego na terenie kraju prawa. Ponadto wskazano na podmiotowy oraz przedmiotowy zakres prawotwórczej działalności organów administracji publicznej oraz poruszono problem weryfikacji przez sądy administracyjne legalności aktów stanowiących efekt legislacji administracyjnej. W opracowaniu dokonano również porównawczej wykładni przepisów Konstytucji RP, regulujących zakres kognicji Trybunału Konstytucyjnego oraz ustanawiających instytucję skargi konstytucyjnej. Artykuł obejmuje również rozważania na temat dopuszczalności wniesienia przez jednostkę skargi konstytucyjnej na powszechnie obowiązujący akt prawa, wydany przez terenowy organ administracji publicznej. Rozważania w tym obszarze zostały wzbogacone prezentacja przeciwstawnych stanowisk przedstawicieli doktryny prawa administracyjnego, dotyczących omawianego problemu. W artykule powołane zostało również postanowienie Trybunału Konstytucyjnego, które wyraża stanowisko tego organu dotyczące możliwości wniesienia przez jednostkę (w ramach kontroli konkretnej) skargi konstytucyjnej na akt prawa miejscowego, na którego podstawie sąd lub organ administracji publicznej orzekł ostatecznie o wolnościach lub prawach obywatela albo o jego obowiązkach określonych w Konstytucji RP. Ponadto w artykule omówiono konstytucyjnie oraz ustawowo określone warunki formalne, którym podlega skarga konstytucyjna.

Słowa kluczowe: terenowe organy administracji publicznej, Trybunał Konstytucyjny,

skarga konstytucyjna, prawo miejscowe.
\end{abstract}

Obserwowany powszechnie proces pogarszania się jakości tworzonego w Polsce prawa niewątpliwie znacznie poteguje dyskusję na temat konstytucyjnych standardów dotyczących procesu powstawania tego prawa. Ponadto formułowane w doktrynie tezy, wskazujące między innymi na istotne elementy mechanizmu tworzenia prawa oraz nieprawidłowości czy też na wymagania - zarówno co do formy, jak i treści powstających przepisów, niestety nie spotykają się ze zdecydowaną reakcją prawodawcy, która faktycznie mogłaby wpłynąć na jakość efektów prac legislacyjnych. W konsekwencji te negatywne procesy się pogłębiają. Jak słusznie zauważa Tomasz Zalasiński, można wysunąć wniosek, że podmiotom tworzącym prawo trudno samodzielnie utrzymywać jego wysoki poziom, ponieważ poza realizacją bieżących celów politycznych brakuje im samodyscypliny pozwalającej dbać zarówno o poziom

\footnotetext{
${ }^{1}$ Dr Małgorzata Polinceusz, Katedra Prawa i Administracji, Wydział Zarządzania, Politechnika Rzeszowska, al. Powstańców Warszawy 6, 35-959 Rzeszów, tel. (0-17) 85244 42, e-mail: malgpope@prz.edu.pl
} 
merytoryczny, jak i jakość tworzonego prawa ${ }^{2}$. W tej sytuacji szczególnego znaczenia nabiera aktywność Trybunału Konstytucyjnego (TK), stojącego na straży przestrzegania ustalonych standardów tworzenia prawa oraz jego konstytucyjności.

Zgodnie $\mathrm{z}$ postanowieniami art. 188 Konstytucji $\mathrm{RP}^{3}$ w związku z art. 10 ust. 2 Konstytucji RP TK jako organ sprawujący władzę sądowniczą orzeka w sprawach:

- $\quad$ zgodności ustaw i umów międzynarodowych z Konstytucją;

- zgodności ustaw z ratyfikowanymi umowami międzynarodowymi, których ratyfikacja wymagała uprzedniej zgody wyrażonej w ustawie;

- zgodności przepisów prawa, wydawanych przez centralne organy państwowe, z Konstytucją, ratyfikowanymi umowami międzynarodowymi i ustawami;

- $\quad$ zgodności z Konstytucją celów lub działalności partii politycznych;

- $\quad$ skargi konstytucyjnej.

Zgodnie z treścią przywołanej regulacji kognicją TK zostały między innymi objęte przepisy prawa wydawane przez centralne organy państwowe, czyli akty legislacji administracyjnej organów administracji publicznej, których zakres działania obejmuje obszar całego państwa. Do tej grupy należą więc rozporządzenia, czyli akty wykonawcze do ustawy, wydawane przez naczelne organy władzy wykonawczej na podstawie upoważnienia udzielonego przez ustawę i w celu wykonania ustawy (wydawane m.in. przez Prezesa Rady Ministrów, Radę Ministrów, ministrów zawiadujących poszczególnymi działami administracji rządowej, Krajową Radę Radiofonii i Telewizji), a także przepisy prawa o charakterze wewnętrznym, stanowione przez uprawnione do tego organy administracji o właściwości działania obejmującej obszar całego państwa, do których należą między innymi centralne organy administracji rządowej ${ }^{4}$. Należy bowiem podkreślić, że przywołane $\mathrm{w}$ tytule niniejszego artykułu powszechnie obowiązujące akty legislacji administracyjnej stanowią jedynie jeden z efektów prawotwórczej działalności podmiotów administracji publicznej. Podmioty te tworzą bowiem również akty o innym charakterze. Wyrazem tej prawotwórczej działalności są więc akty o charakterze podustawowym o charakterze powszechnie obowiązującym (rozporządzenia wydawane przez organy upoważnione do tego w Konstytucji RP oraz akty prawa miejscowego, które przyjmować będą formę rozporządzeń, uchwał lub zarządzeń wydawanych przez terenowe organy administracji rządowej i organy samorządu terytorialnego) oraz akty prawa wewnętrznego (zarówno te określone konstytucyjnie, jak i te pozakonstytucyjne, regulujące przede wszystkim wewnętrzną organizację struktur administracji publicznej) $)^{5}$.

Możliwość sprawowania kontroli przez TK nad wymienionymi aktami, stanowionymi przez państwowe organy centralne, nie budzi wątpliwości. Dyskusję wzbudza natomiast

\footnotetext{
${ }^{2}$ T. Zalasiński, Zasada prawidłowej legislacji w pogladach Trybunału Konstytucyjnego, Warszawa 2008, s. 8

${ }^{3}$ Konstytucja Rzeczypospolitej Polskiej z 2 kwietnia 1997 r., DzU 1997 nr 78, poz. 483 ze zm., dalej jako: Konstytucja RP.

4 Szerzej: T. Bąkowski, Sqdowa kontrola legislacji administracyjnej, [w:] Zarys legislacji administracyjnej. Uwarunkowania i zasady prawotwórczej działalności administracji publicznej, red. T. Bąkowski, Wrocław 2010, s. 152.

${ }^{5}$ M. Polinceusz, Kilka uwag na temat rozumienia pojęcia „legislacja administracyjna”, „Zeszyty Naukowe Wyższej Szkoły Informatyki, Zarządzania i Administracji w Warszawie” 23/2 (2013), s. 164.
} 
możliwość objęcia zasięgiem działania TK powszechnie obowiązujących aktów legislacji administracyjnej, stanowionych przez podmioty administracji terenowej.

Należy bowiem zauważyć, że w świetle Konstytucji RP do prawotwórczej działalności o charakterze powszechnie obowiązującym umocowane zostały nie tylko centralne organy administracji, lecz również niektóre z jej organów terenowych. Zgodnie z regulacją wynikającą $\mathrm{z}$ art. 94 Konstytucji RP uprawnione do wydawania aktów prawa miejscowego ${ }^{6}$ są organy samorządu terytorialnego oraz terenowe organy administracji rządowej. Bezpośrednie wskazanie tych organów znajduje się w ustawach ustrojowych ${ }^{7}$, na których podstawie w kompetencje do tworzenia prawa miejscowego wyposażone zostały rady gmin, rady powiatów, sejmiki województw oraz warunkowo i w sytuacjach wyjątkowych organy wykonawcze gmin i powiatów, wojewodowie i niektóre grupy organów rządowej administracji niezespolonej.

Problem kognicji TK, obejmującej powszechnie obowiązujące akty legislacji administracyjnej terenowych organów administracji publicznej, wynika z tego, że ani określający zakres działania TK art. 188 Konstytucji RP, ani też przepisy ustawy z 1 sierpnia 1997 r. o Trybunale Konstytucyjnym ${ }^{9}$ nie przewidują wprost możliwości kontroli konstytucyjności tych aktów jako przedmiotu działania $\mathrm{TK}^{10}$. Wyraźna regulacja ustrojowa wnioskami do TK o zbadanie konstytucyjności aktu obejmuje wyłącznie akty legislacji administracyjnej wydawane przez centralne organy administracji publicznej.

Oczywiście, powszechnie obowiązujące akty legislacji administracyjnej terenowych organów administracji publicznej podlegają kontroli sądów administracyjnych, ale kontrola ta może mieć na celu weryfikację legalności tych aktów, nie obejmuje ona natomiast możliwości wydawania orzeczeń w zakresie ich konstytucyjności. Wniosek ten wynika wprost z Konstytucji RP. Zgodnie z postanowieniami art. 184 ustawy zasadniczej kontrola Naczelnego Sądu Administracyjnego oraz sądów administracyjnych obejmuje orzekanie o zgodności uchwał organów samorządu terytorialnego i aktów normatywnych terenowych organów administracji rządowej $\mathrm{z}$ ustawami, a nie $\mathrm{z}$ konstytucją. W przypadku gdy przy okazji rozpoznawania konkretnej sprawy sąd podda w wątpliwość konstytucyjność podstawy prawnej rozstrzygnięcia, może on skierować pytanie prawne do $\mathrm{TK}^{11}$, nie rozstrzyga jednak tej kwestii samodzielnie ${ }^{12}$.

W tej sytuacji jedyną możliwością weryfikacji konstytucyjności powszechnie obowiązujących norm aktów legislacji administracyjnej wydawanych przez terenowe

\footnotetext{
${ }^{6}$ Zgodnie z postanowieniami art. 87 ust. 2 Konstytucji RP akty prawa miejscowego stanowią osobną kategorię powszechnie obowiązujących źródeł prawa na obszarze działań organów, które je ustanowiły.

${ }^{7}$ Ustawa z 8 marca 1990 r. o samorządzie gminnym, t.j. DzU 2013 poz. 594., ze. zm; Ustawa z 5 czerwca 1998 r. o samorządzie powiatowym, t.j. DzU 2013 poz. 595 ze zm.; Ustawa z 5 czerwca 1998 r. o samorządzie województwa, t.j. DzU 2013 poz. 596 ze zm.; Ustawa z 23 stycznia 2009 r. o wojewodzie i administracji rządowej w województwie, DzU $2009 \mathrm{nr} 31$, poz. 206 ze zm.

${ }^{8}$ Szerzej: M. Polinceusz, Funkcje wojewody. Studium administracyjnoprawne, Rzeszów 2010, s. $170 \mathrm{n}$.

${ }^{9}$ DzU 1997 nr 102, poz. 643 ze zm., dalej jako: ustawa o TK.

${ }^{10}$ T. Bąkowski, Sadowa kontrola..., s. 152.

${ }^{11}$ Artykuł 3 ustawy o TK

${ }^{12}$ Szerzej: D. Dąbek, Prawo miejscowe, Warszawa 2007, s. 300 n.
} 
organy administracji publicznej jest skarga konstytucyjna. Ta teza nie znajduje jednak poparcia części przedstawicieli doktryny, którzy podkreślają, że ustrojodawca za pośrednictwem art. 188 Konstytucji RP precyzyjnie określił akty normatywne objęte kontrolą TK (ustawy, ratyfikowane umowy międzynarodowe oraz akty normatywne stanowione przez centralne organy państwa) i tym samym wyznaczył ramy przedmiotowe dla wszystkich możliwych postępowań kontrolnych tego organu. W związku z tym pozostałe akty legislacji administracyjnej takiej kontroli nie podlegają. Zgodnie $\mathrm{z}$ prezentowanym stanowiskiem art. 79 Konstytucji RP, formułujący prawo do skargi konstytucyjnej, nie może stanowić autonomicznej, dodatkowej normy kompetencyjnej dla $\mathrm{TK}^{13}$.

Uznanie tego poglądu za słuszny oznaczałoby jednak wyłączenie możliwości weryfikacji konstytucyjności części aktów powszechnie obowiązującego prawa, za których pośrednictwem również regulowana jest sytuacja prawna obywatela. Jak słusznie zauważa Dorota Dąbek: ,sprzeczne z zasadą demokratycznego państwa prawnego byłoby przyjęcie, że obywatel jest przed niekonstytucyjnym aktem prawa miejscowego chroniony gorzej niż przed niekonstytucyjnym aktem stanowionym przez organy centralne"14. Ponadto za możliwością zastosowania skargi konstytucyjnej wobec aktów prawa miejscowego przemawia również wykładnia art. 79 Konstytucji RP. Zgodnie z treścią tej regulacji każda osoba, której konstytucyjne wolności lub prawa zostały naruszone, ma prawo wnieść skargę do Trybunału Konstytucyjnego w sprawie zgodności z Konstytucją ustawy lub innego aktu normatywnego, na którego podstawie sąd lub organ administracji publicznej orzekł ostatecznie o jego wolnościach lub prawach albo o jego obowiązkach określonych w Konstytucji. Użycie w tym artykule zwrotu „ustawa lub inny akt normatywny" oznacza, że przedmiot skargi stanowiącej podstawę niekorzystnego dla obywatela rozstrzygnięcia został przez ustrojodawcę określony bardzo szeroko. Niewątpliwie wśród kategorii ,innych aktów normatywnych” można bez przeszkód ulokować powszechnie obowiązujące akty prawa, stanowione przez terenowe organy administracji publicznej, tym samym czyniąc je przedmiotem kontroli konkretnej $\mathrm{TK}^{15}$.

W tej kwestii wypowiedział się też sam TK, który w postanowieniu z 6 lutego 2001 roku podkreślił, że dostrzega możliwość uczynienia przedmiotem skargi konstytucyjnej aktów prawa miejscowego, pod warunkiem że „mają one charakter normatywny i mogą być zaliczone do aktów normatywnych w rozumieniu konstytucyjnym, czyli powszechnie obowiązującego prawa, zawierającego normy generalne i abstrakcyjne. Zakres przepisów podlegających zaskarżeniu (przedmiot skargi konstytucyjnej) ustala bowiem autonomicznie i wyczerpująco art. 79 ust. 1 Konstytucji RP. Wyłączenie spoza zasięgu skargi konstytucyjnej prawa miejscowego byłoby także sprzeczne z art. 188 pkt 5 Konstytucji RP, który wyraźnie wiąże kognicję Trybunału Konstytucyjnego z regulacją art. 79 ust. 1, w tym $\mathrm{z}$ pojęciem «innego aktu normatywnego»"16.

Zasady wniesienia skargi konstytucyjnej zostały określone postanowieniami ustawy o TK. W świetle tych regulacji skarga konstytucyjna może być wniesiona pod warunkiem

\footnotetext{
${ }^{13}$ B. Banaszak, Prawo konstytucyjne, Warszawa 1999, s. 410; Z. Czeszejko-Sochacki, Skarga konstytucyjna w prawie polskim, „Przegląd Sejmowy” 1998/1, s. 46 n.

${ }^{14}$ D. Dąbek, op. cit., s. 303.

${ }^{15}$ Podobnie: P. Lisowski, A. Ostapski, Akty prawa miejscowego stanowione przez terenowe organy administracji rzqdowej, Wrocław 2008 s. 105; D. Dąbek, op. cit., s. 303.

${ }^{16}$ Postanowienie Trybunału Konstytucyjnego z 6 lutego 2001 r., Ts 139/00, LEX.
} 
wyczerpania drogi prawnej, o ile droga ta jest przewidziana, w ciagu 3 miesięcy od doręczenia skarżącemu prawomocnego wyroku, ostatecznej decyzji lub innego ostatecznego rozstrzygnięcia $^{17}$. Skarga, spełniając wymogi dotyczące pisma procesowego, powinna również zawierać dokładne określenie ustawy lub innego aktu normatywnego, na którego podstawie sąd lub organ administracji publicznej orzekł ostatecznie o wolnościach lub prawach albo obowiązkach określonych w Konstytucji RP i w stosunku do którego skarżący domaga się stwierdzenia niezgodności z Konstytucją RP. Ponadto ustawodawca wymaga określenia konstytucyjnych praw lub wolności, które zdaniem skarżącego zostały naruszone, oraz wskazania sposobu ich naruszenia. Niezbędnym elementem skargi jest również jej uzasadnienie, z podaniem dokładnego opisu stanu faktycznego. Zgodnie $\mathrm{z}$ dyspozycją ustawodawcy do skargi należy załączyć wyrok, decyzję lub inne rozstrzygnięcie, z podaniem daty jej doręczenia, wydane na podstawie zakwestionowanego aktu normatywnego $^{18}$. Zarówno skargę, jak i zażalenie na postanowienie o odmowie nadania skardze dalszego biegu mogą sporządzić adwokat lub radca prawny (przymus adwokacki), chyba że skarżącym jest sędzia, prokurator, notariusz, profesor lub doktor habilitowany nauk prawnych ${ }^{19}$. Rozpatrzenie skargi konstytucyjnej kończy wydanie wyroku, w którym TK stwierdza zgodność bądź niezgodność kwestionowanego aktu normatywnego z zawartym w zarzucie skargi wzorcem konstytucyjnym. Orzeczenie to jest ostateczne i ma moc powszechnie obowiązującą $^{20}$.

Problematyka tworzenia prawa ma szczególne znaczenie dla prawa administracyjnego, ponieważ coraz częściej realizacja zadań przez podmioty administracji publicznej obfituje właśnie w działania o charakterze legislacyjnym. Efektywność i skuteczność tej działalności zależą jednak od poziomu tych procesów normotwórczych. Precyzyjne oraz merytorycznie prawidłowe rozstrzygnięcia prawodawcy w postaci dobrego prawa stanowią bowiem jedno $\mathrm{z}$ najważniejszych oraz kluczowych narzędzi zarządzania państwem.

Powszechnie obowiązujące akty legislacji administracyjnej terenowych organów administracji publicznej, dotykając bezpośrednio sfery praw oraz wolności obywateli, nie mogą zostać pozbawione możliwości weryfikacji, również w zakresie ich konstytucyjności. Często występująca wadliwość tych aktów prawdopodobnie spowodowana jest tym, że do tej pory nie zostały wprowadzone - jednolite w skali kraju zasady stanowienia prawa miejscowego. Nie wprowadzono również w tym obszarze wiążących ustaleń terminologicznych ani nie ujednolicono zasad techniki legislacyjnej. W tej sytuacji nie tylko dopuszczalne, ale wręcz konieczne staje się objęcie powszechnie obowiązujących aktów prawa lokalnego kontrolą konstytucyjności, sprawowaną przez TK. Nadrzędnym celem działania tego organu jest bowiem zapewnienie spójności systemu prawnego, co z kolei gwarantuje możliwość realizacji konstytucyjnie sformułowanych praw i wolności obywateli.

\footnotetext{
${ }^{17}$ Artykuł 46 ust. 1 ustawy o TK.

${ }^{18}$ Ibidem, art. 47 ust. 1-2.

${ }^{19}$ Ibidem, art. 48 ust. 1.

${ }^{20}$ J. Repel, Skutki prawne orzeczenie Trybunatu Konstytucyjnego w sprawie skargi konstytucyjnej, [w:] Skarga konstytucyjna, red. J. Trzciński, Warszawa 2000, s. 202; P. Lisowski, A. Ostapski, op. cit., s. 106.
} 


\section{LITERATURA}

[1] Bąkowski T., Sadowa kontrola legislacji administracyjnej, [w:] Zarys legislacji administracyjnej. Uwarunkowania $i$ zasady prawotwórczej działalności administracji publicznej, red. T. Bąkowski, Wrocław 2010.

[2] Banaszak B., Prawo konstytucyjne, Warszawa 1999.

[3] Czeszejko-Sochacki Z., Skarga konstytucyjna w prawie polskim, „Przegląd Sejmowy" 1998/1.

[4] Dąbek D., Prawo miejscowe, Warszawa 2007.

[5] Lisowski P., Ostapski A., Akty prawa miejscowego stanowione przez terenowe organy administracji rzqdowej, Wrocław 2008.

[6] Polinceusz M., Funkcje wojewody. Studium administracyjnoprawne, Rzeszów 2010

[7] Polinceusz M., Kilka uwag na temat rozumienia pojęcia „legislacja administracyjna”, „Zeszyty Naukowe Wyższej Szkoły Informatyki, Zarządzania i Administracji w Warszawie" 23/2 (2013).

[8] Zalasiński T., Zasada prawidtowej legislacji $w$ pogladach Trybunatu Konstytucyjnego, Warszawa 2008.

\section{GENERALLY APPLICABLEACTS OFLEGISLATIONAS A MATTER OF ADMINISTRATIVE CONTROL OF THE CONSTITUTIONAL COURT}

The subject of considerations of this article are the problems associated with the ability to verify the constitutionality of acts of universally binding law, constituted by the local organs of public administration. In the paper it was discussed the constitutionally defined scope of the Constitutional Court as a body exercising judicial power in Poland and standing guard over the constitutionality of the existing law in the country. The personal and material scope of a law-making activities of public bodies was emphasized as well as the problem of verification by the administrative courts the legality of the acts constituting the effect of administrative legislation. In the article it was also made a comparative interpretation of the provisions of the Constitution governing the jurisdiction of the Constitutional Court and establishing the institution of a constitutional complaint. The paper also includes reflections on the admissibility of actions brought by the constitutional complaint generally binding legal act issued by a local public authority. The considerations in this area have been enhanced by the presentation of opposing positions of representatives of the doctrine of administrative law concerning that problem. In the article the Constitutional Court decisionhas also been established, which expresses the position of the body on the possibility of an entity (within the actual control) constitutional complaint about the local law under which a court or public authority has finally decided about freedoms or rights of the citizen, or about their obligations specified in the Constitution. In addition, the article discusses the constitutionally and statutorily defined formal conditions governing the constitutional complaint. Considerations which are the subject of this article end with a summary and conclusions.

Keywords: local organs of public administration, Constitutional Court, constitutional complaint, local law.

DOI:10.7862/rz.2014.hss.65

Przesłano do redakcji: październik 2014

Przyjęto do druku: grudzień 2014 